\title{
Effect of Celastrol on Growth Inhibition of Prostate Cancer Cells through the Regulation of hERG Channel In Vitro
}

\author{
Nan Ji, ${ }^{1,2}$ Jinjun Li, ${ }^{1}$ Zexiong Wei, ${ }^{3}$ Fanhu Kong, ${ }^{3}$ Hongyan Jin, \\ Xiaoya Chen, ${ }^{1}$ Yan Li, ${ }^{4}$ and Youping Deng ${ }^{1}$ \\ ${ }^{1}$ Medical College, Wuhan University of Science and Technology, Wuhan 430065, China \\ ${ }^{2}$ The Outpatient Department, The Second Affiliated Hospital, Zhejiang University School of Medicine, Hangzhou 310009, China \\ ${ }^{3}$ Puren Hospital Affiliated to Wuhan University of Science and Technology, Wuhan 430081, China \\ ${ }^{4}$ Department of Internal Medicine, Rush University Medical Center, Chicago, IL 60121, USA
}

Correspondence should be addressed to Jinjun Li; entry2003@126.com and Youping Deng; youpingd@gmail.com

Received 30 June 2014; Accepted 28 July 2014

Academic Editor: Hongwei Wang

Copyright (C) 2015 Nan Ji et al. This is an open access article distributed under the Creative Commons Attribution License, which permits unrestricted use, distribution, and reproduction in any medium, provided the original work is properly cited.

\begin{abstract}
Objective. To explore the antiprostate cancer effects of Celastrol on prostate cancer cells' proliferation, apoptosis, and cell cycle distribution, as well as the correlation to the regulation of hERG. Methods. DU145 cells were treated with various concentrations of Celastrol $(0.25-16.0 \mu \mathrm{mol} / \mathrm{L})$ for $0-72$ hours. MTT assay was used to evaluate the inhibition effect of Celastrol on the growth of DU145 cells. Cell apoptosis was detected through both Annexin-V FITC/PI double-labeled cytometry and Hoechst 33258. Cell cycle regulation was examined by a propidium iodide method. Western blot and RT-PCR technologies were applied to assess the expression level of hERG in DU145 cells. Results. Celastrol presented striking growth inhibition and apoptosis induction potency on DU145 cells in vitro in a time- and dose-dependent manner. The $\mathrm{IC}_{50}$ value of Celastrol for 24 hours was $2.349 \pm 0.213 \mu \mathrm{mol} / \mathrm{L}$. Moreover, Celastrol induced DU145 cell apoptosis in a cell cycle-dependent manner, which means Celastrol could arrest DU145 cells in $G_{0} / G_{1}$ phase; accordingly, cells in $S$ phase decreased gradually and no obvious changes were found in $G_{2} / M$ phase cells. Through transmission electron microscope, apoptotic bodies containing nuclear fragments were found in Celastrol-treated DU145 cells. Overexpression of hERG channel was found in DU145 cells, while Celastrol could downregulate it at both protein and mRNA level in a dose-dependent manner $(P<0.01)$. Conclusions. Celastrol exhibits its antiprostate cancer effects partially through the downregulation of the expression level of hERG channel in DU145 cells, suggesting that Celastrol may be a potential agent against prostate cancer with a mechanism of blocking the hERG channel.
\end{abstract}

\section{Foreword}

Ion channels exist widely in all cells in a variety of physiological functions. Cancer is also associated with ion channel dysfunction. Research [1] recently suggested that some potassium channels (voltage-gated potassium channels, KV) are related to the occurrence and development of malignant tumors, and the relationship between voltage-gated potassium channels and tumor has become a research hotspot. The human EAG gene (human ether-à-go-go related gene, HE$\mathrm{RG}$ ) encodes the HERG protein A subunit of delayed rectifier potassium channel. Researches have found that [2] high expression of HERG protein in tumor cells has a widespread impact on the biological behavior of tumors and is closely related to the differentiation and invasion of tumor cell proliferation and apoptosis [3-5]. There are reports that hERG protein can affect the tumor cell membrane potential in the depolarized state, which is conducive to tumor cell survival, proliferation, and invasion [5]. Therefore, hERG potassium channel will become a promising target for cancer therapy in the selection of specific molecular targeted agents that play an important role in the process. Celastrol (CSL) is one of the main active components extracted from the traditional Chinese medicine Tripterygium wilfordii. A general and three-terpene pigment monomer, Celastrol, is found early to have anti-inflammatory and antitumor pharmacological effects on liver cancer, colon cancer, lung cancer, leukemia, cancer of the esophagus, brain cancer, bladder cancer, and so 
on. Much tumor cell growth and proliferation were inhibited $[6,7]$. But its antitumor mechanism has only in recent years seen sporadic reports. Its role in the regulation of hERG potassium channel protein has not been reported. Therefore in this paper, with hERG potassium channel as the molecular target, the effect of different concentration of tripterine on its regulation and tripterine antitumor effect correlation will be investigated.

\section{Materials and Methods}

2.1. Drugs and Reagents. Tripterine, molecular formula (C29$\mathrm{H} 38 \mathrm{O} 4$ ), a molecular weight of 450 , and purity more than 95\%, was purchased from USA Calbiochem company, dissolved in two dimethyl sulfoxide (DMSO), and kept at $-20^{\circ} \mathrm{C}$, before using DMEM culture medium diluted to final concentration. DMEM medium and fetal calf serum were from the USA Gibco BRL company. Annexin-V/PI apoptosis kits were purchased from Wuhan Boster Engineering Co., Ltd. Rabbit anti-human hERG1 monoclonal antibody was purchased from Sigma company, HRP standard. Sheep anti free, two anti purchased from USA Santa Cruz products. Bio-Rad protein assay kit, TRIzol kit, and ECL lighting kits originated from Sweden Amersham company. RT-PCR kit was purchased from Fermentas company. Primers were synthesized by Shanghai Sangon company.

2.2. Cell Lines and Cell Culture. Prostate cancer cell DU145 was obtained from Tongji Medical College, Department of Immunology. Medium contained $10 \%$ fetal bovine serum, penicillin $100 \mathrm{IU} / \mathrm{mL}$, and streptomycin $100 \mathrm{~g} / \mathrm{mL}$ DMEM, at $37^{\circ} \mathrm{C}, 5 \% \mathrm{CO}_{2}$, and water saturated humidity condition. Every $1 \sim 2$ days, for a fluid passage, the logarithm growth period of cell activity of more than $98 \%$ cells was used in this study.

2.3. Effects of Tripterygium wilfordii Red MTT Method to Detect the Proliferation of DU145 Cells. Logarithmic growth phase DU145 cell experiments, cells per hole $2 \times 10^{5} / \mathrm{mL}$ cells were seeded in 96-well plate, adding different concentrations of celastrol $(0.25-16.0 \mu \mathrm{mol} / \mathrm{L})$, with the culture solution containing equal volume DMSO as blank control, each drug concentration group with 3 holes, each hole total volume $200 \mu \mathrm{L}$. For $5 \% \mathrm{CO}_{2}, 37^{\circ} \mathrm{C}$ incubator culture $24-72 \mathrm{~h}$, each hole with $5 \mathrm{mg} / \mathrm{mL}$ MTT $20 \mu \mathrm{L}$ reagent, $37^{\circ} \mathrm{C}$ incubate for $4 \mathrm{~h}$, carefully to absorb the air in culture supernatant, DMSO solution was added to each well of $150 \mu \mathrm{L}, 10 \mathrm{~min}$ oscillation, crystallize fully dissolved in the Bio-Rad M450 enzyme labeled each hole optical density were measured in $492 \mathrm{~nm}$ wavelength 1.25 meter value (OD), with each experiment repeated 1.273 times, to calculate the inhibitory rate of cell proliferation. Proliferation inhibition rate $(\%)=$ $(1$ - experimental group, control group od/OD) $\times 100 \%$.

2.4. Annexin-V/PI Staining to Detect Apoptosis. Operate according to kit, divided into the experimental group and the control group with single standard. A collection of different concentration of tripterine $(1,2$ and $4 \mu \mathrm{mol} / \mathrm{L})$ DU145 cells and blank treated cells in control group, with $4^{\circ} \mathrm{C}$ ice cold
PBS wash 2 times, and then to $1 \times 10^{6} / \mathrm{mL}$ cell density weight suspended from $100 \mu \mathrm{L}$ binding buffer, adding $5 \mu \mathrm{L}$ Annexin$\mathrm{V}$ and $10 \mu \mathrm{L}$ PI dye solution, mix gently, light reaction temperature $15 \mathrm{~min}$, add $300 \mu \mathrm{L}$ of the buffer solution, detection of it within $1 \mathrm{~h}$.

2.5. Hoechst 33258 Staining for Detection of Cell Morphology of Apoptosis. The logarithmic growth phase DU145 cell was $5 \times 10^{5}$ cells, join the 6 hole plate with cover glass. Blank group and tripterine $\mathrm{IC}_{50} 100 \mu \mathrm{mol} / \mathrm{L}$ dosing experiment group, after $24 \mathrm{~h}$ incubation, washed two times with PBS, then with fixed liquid (methanol: acetic acid $=3: 1$ ) fixed $15 \mathrm{~min}$, washed two times with PBS; $37^{\circ} \mathrm{C}$ Hoechst 33258 staining solution $(5 \mathrm{mg} / \mathrm{L})$ staining of $15 \sim 30 \mathrm{~min}$, PBS wash two times; neutral resin sheet, fluorescent cell morphology was observed under microscope and photographed. Mirror were found 5 does not repeat, apoptotic cell count per 200 cells, the percentage of apoptotic cells is the apoptosis rate.

2.6. The Cell Cycle Was Detected by Flow Cytometry. Collection of the treated DU145 cell was $1 \times 10^{6}$, washing with PBS buffer 2 times, with $70 \%$ cold ethanol at $4^{\circ} \mathrm{C}$ fixed overnight, centrifugation, washing 1 time with PBS, adding $20 \mu \mathrm{L}$ RNase A at $37^{\circ} \mathrm{C}$ water bath for $30 \mathrm{~min}$ and then adding $300 \sim 500 \mu \mathrm{L}$ PI dye solution mixing and placing $4^{\circ} \mathrm{C}$ under dark condition for $30 \mathrm{~min}$; the cell cycle was detected by flow cytometry, with red fluorescent wavelength at $488 \mathrm{~nm}$.

2.7. Effects of Tripterygium wilfordii by Semiquantitative RTPCR Detection of Red Pigment on the Expression of HERG Gene in DU145 Cells. TRIzol kit was used to extract to-tal cellular RNA synthesis of cDNA, according to the instructions. In the first chain cDNA cells were used as template, PCR reaction. PCR primer was synthesized by Sangon company in Shanghai, of which hERG gene upstream primer was $5^{\prime}$-CAGCGGCTGTACTCGGGCACAG-3', downstream primer was $5^{\prime}$-CAGAAGTGGTCGGAGAACTC-3', amplified fragment is $345 \mathrm{bp}$; 3-glyceraldehyde phosphate dehydrogenase gene $(\mathrm{GAPDH})$ upstream primer is $5^{\prime}$-GATTTGGTCGTATTGGGGCGC-3', downstream primer is $5^{\prime}$-CAGAGATGACCCTTTTGGCTCC- $3^{\prime}$, amplified fragment is $136 \mathrm{bp}$. The PCR amplification conditions were $95^{\circ} \mathrm{C}$ denaturing $5 \mathrm{~min}, 94^{\circ} \mathrm{C} 1 \mathrm{~min}, 55^{\circ} \mathrm{C}$ $50 \mathrm{~s}, 72^{\circ} \mathrm{C} 1 \mathrm{~min}$, cycle $35,72^{\circ} \mathrm{C} 10 \mathrm{~min}$ end reaction. PCR products were detected by $1.5 \%$ agarose gel electrophoresis, UV photography, and scanning analysis, the hERG/GAPDH expression of hERG semiquantitative analysis of the level of.

2.8. Detection of Western Blot Methods. Different concentrations of tripterine treated DU145 cells and control cells, with cell lysate $100 \mu \mathrm{L}$ pre-cooling (configuration according to molecular cloning method) the ice cracking $30 \mathrm{~min}$, extraction of total cellular protein, quantitative protein by Lowry method. Conventional adhesive preparation, sampling, protein electrophoresis, and then transferring to the membrane were done. Rabbit anti-human hERG1 monoclonal antibodies were added $(1: 1500), 4^{\circ} \mathrm{C}$ overnight incubation. Rinse after adding HRP-labeled goat anti-rabbit $\operatorname{IgG}(1: 2000)$, at $37^{\circ} \mathrm{C}$ 
with shaking and incubation for $1 \mathrm{~h}$. Finally, ECL chemiluminescence reagent, $\mathrm{X}$-ray exposure and development, analysis of computer software. Each concentration was repeated 3 times, taking the mean measurement results.

2.9. Statistical Analysis. Experimental data $\bar{X} \pm S$, among groups, were compared using $F$ test, SPSS 11.5 statistical software analysis.

\section{Results}

3.1. Effects of Tripterine on Proliferation of DU145 Cells. It can be seen from Figure 1, respectively, by $0.25,0.5,1,2,4,8$, and $16 \mu \mathrm{mol} / \mathrm{L}$ tripterine in DU145 cells after $24 \sim 72 \mathrm{~h}$, that cell proliferation activity in different cell groups was lower than that of control cells, but in a concentration less than $1 \mu \mathrm{mol} / \mathrm{L}$, proliferation effects of tripterine on DU145 cells are small, and when the tripterine concentration reached $1 \mu \mathrm{mol} / \mathrm{L}$, the proliferation inhibition activity was significantly increased, with significant difference $(P<0.05)$. And, with the increase of tripterine drug concentration and action time, the inhibitory effects of proliferation were enhanced, and an obvious time dose effect relationship is apparent. The $24 \mathrm{~h}$ $\mathrm{IC}_{50}$ value was $2.349 \pm 0.213 \mu \mathrm{mol} / \mathrm{L}$.

3.2. Effects of Tripterine on Apoptosis of DU145 Cells. The Hoechst 33258 results can be seen. DU145 cells of $2 \mu \mathrm{mol} / \mathrm{L}$ tripterine acid treatment in typical apoptosis morphological changes are as follows: cytoplasmic density, chromosome condensation, marginalization, nuclear condensation, and formation of apoptotic bodies increased (Figure 2(a)). Then the Annexin-V/PI double staining (Figure 2(b)) quantitative detection results show that, with the increase of tripterine concentration, apoptosis of DU145 cells gradually increases the proportion, respectively, $(6.57 \pm 0.11) \%,(11.02 \pm 3.10) \%$, and $(23.23 \pm 1.56) \%$ and the control group $(2.24 \pm 1.08) \%$ in comparison and the difference had statistical significance.

3.3. Effects of Celastrol on the Cell Cycle of DU145 Cells. With different concentrations of tripterine and the role of DU145 cells after $24 \mathrm{~h}$, the cell cycle distribution has also been changed, as shown in Figure 3. With the increase of tripterine concentration, the percentage of $\mathrm{G}_{0} / \mathrm{G}_{1}$ phase cells increased gradually, followed by $(39.95 \pm 1.88) \%$, $(40.48 \pm 2.34) \%$, $(51.40 \pm 1.96) \%$, and $(68.58 \pm 2.89) \%$, while the percentage of cells in $S$ phase was dose-dependently reduced, followed by $(49.45 \pm 1.67) \%$, $(46.19 \pm 1.86) \%$, $(37.67 \pm 2.03) \%$, and $(23.29 \pm 1.52) \%$; in contrast, Celastrol effects on $\mathrm{G}_{2} / \mathrm{M}$ cells were not significant (Table 1). This indicates that Celastrol induced DU145 cell cycle arrest occurs in $G_{0} / G_{1}$.

\subsection{Regulatory Effect of Tripterine on DU145 Cells of hERG Po-} tassium Channel Protein. Compared with normal mononuclear cells, the presence of hERG potassium channel protein expression levels was higher in DU145 cells and the $0.5 \sim 2.0 \mu \mathrm{mol} / \mathrm{L}$ tripterine was treated for $24 \mathrm{~h}$. The protein expression had a concentration dependent decline, with a statistically significant difference $(P<0.05)$. In order to

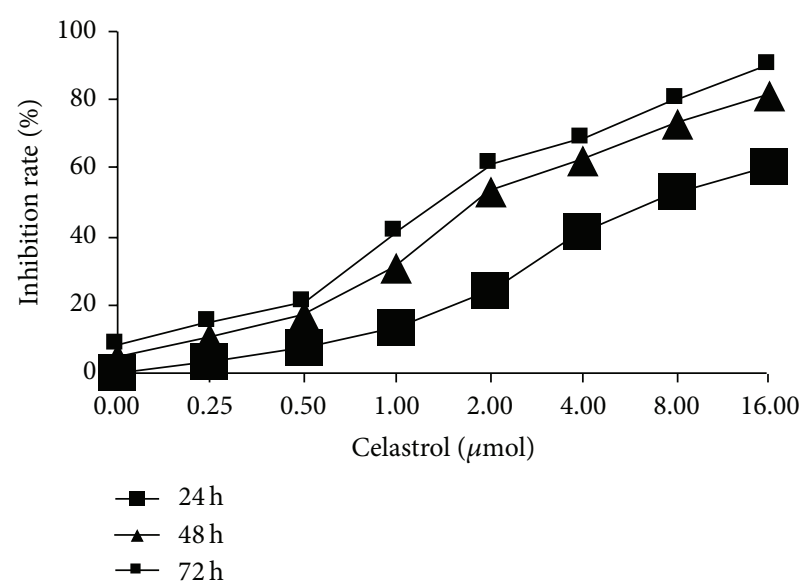

FIGURE 1: Effects of Celastrol on the proliferation of DU145 cells.

further clarify the role of Tripterygium wilfordii red on the hERG protein, we examined the changes of hERG protein and mRNA content in the level of gene transcription. Similarly, hERG potassium channel protein level of mRNA was dosedependently downregulated and obviously higher than the mononuclear cells of normal hERG gene expression level (Figure 4).

\section{Discussion}

People have found that many natural preparations, especially in plants and food components, have significant antitumor activity in vitro and in vivo. In the early 1970s, there were reports of tripterine having anti-inflammatory, analgesic, antioxidant, and antiviral effects, and inducing apoptosis of tumor cells is more positive. Further, to determine the effective components of gambogic acid differently from the general characteristics of anticancer drugs, it can selectively kill tumor cells, but normal hematopoietic cells and heart, liver, kidney, and other organs showed no obvious damage, so it is considered to be a safe and effective antitumor drug $[8,9]$ for long-term continuous use. The antitumor mechanism has had some scattered reports, but studies in prostate cancer are very rare. In this experiment, cultured prostate cancer cell line DU145 is used as the research object to observe the effect of tripterine on DU145 cell growth inhibition and apoptosis induction and to explore its possible molecular mechanism.

The results show that Celastrol can inhibit the proliferation of DU145 cells and the inhibition is associated with the duration of drug action and drug concentration. At the same time, Celastrol can induce apoptosis of DU145 cells through strong $0.5 \sim 2.0 \mu \mathrm{mol} / \mathrm{L}$ tripterine treated for $24 \mathrm{~h}$, the apoptosis rate of DU145 cells increased significantly, and the typical morphological changes of cell apoptosis emerged. The Celastrol-induced apoptosis of cycle arrest effect may be related to induction of closely related events. With the increase of tripterine concentration, the percentage of $G_{0} / G_{1}$ phase cells increased gradually and the percentage of cells in $S$ phase decreased gradually and the tripterine had little effect on the percentage of cells in $\mathrm{G}_{2} / \mathrm{M}$ phase. That Celastrol 

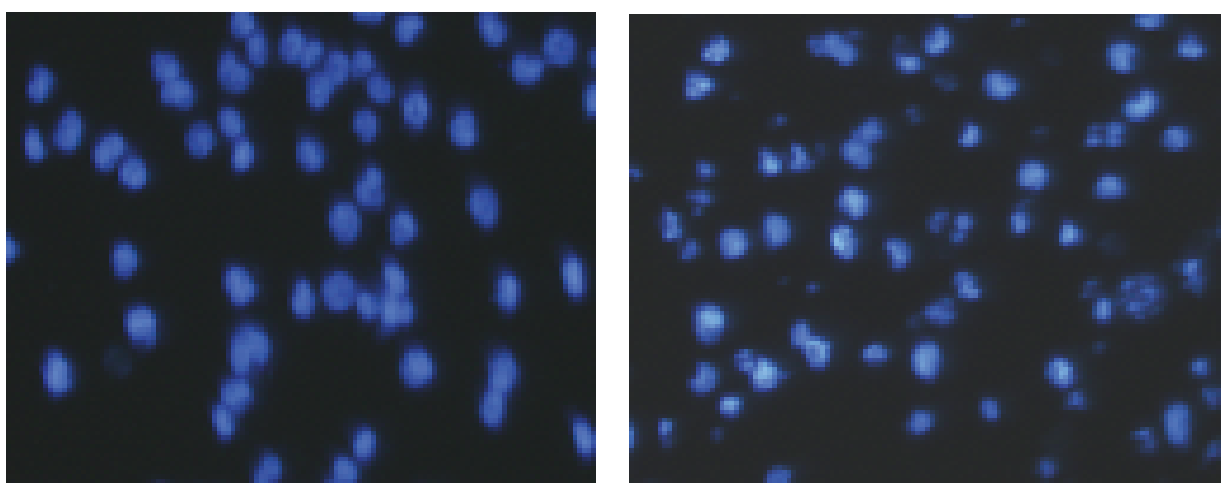

(a) Blank control group Celastrol $2.0 \mu \mathrm{mol} / \mathrm{L}$
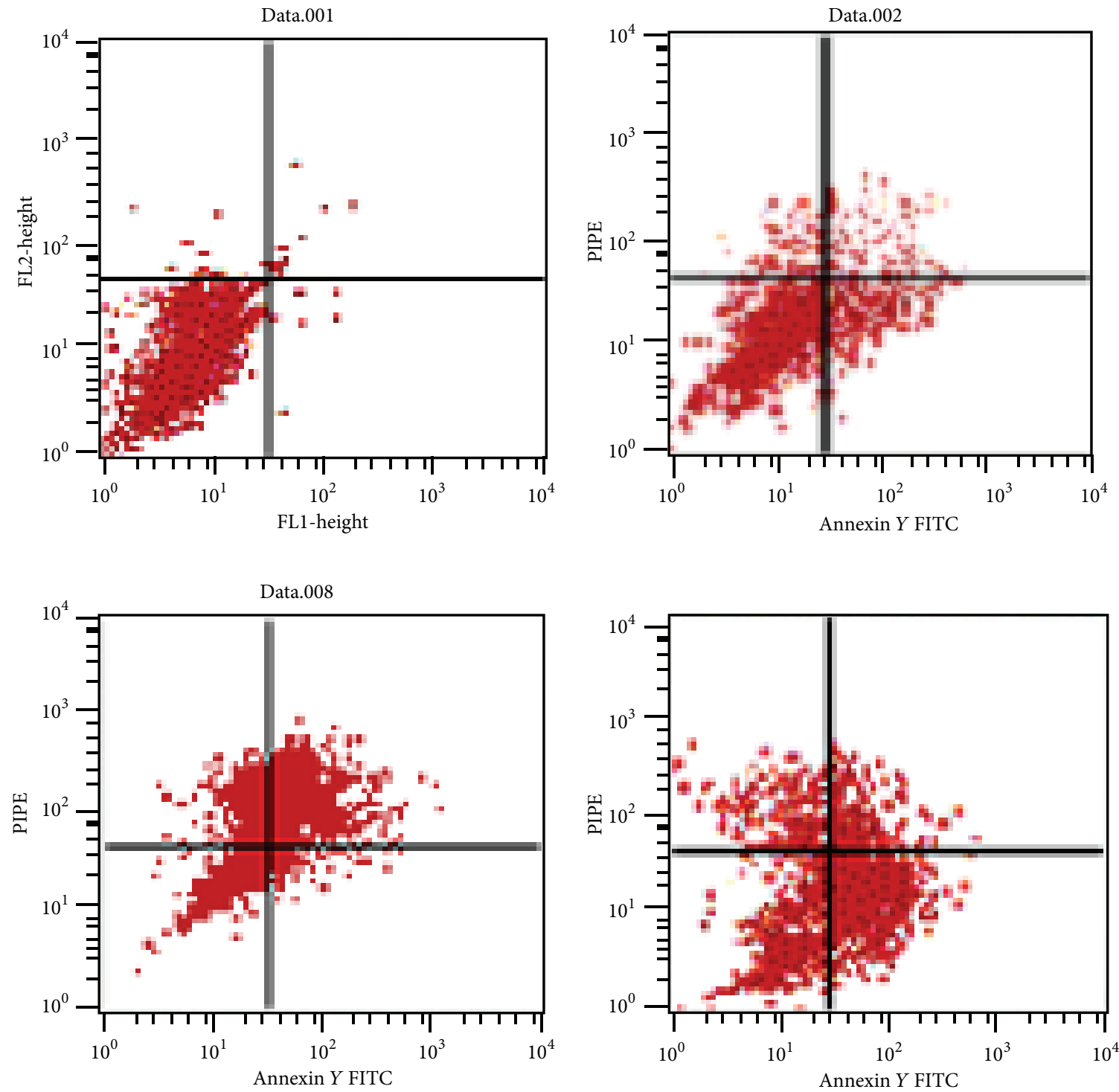

(b) Blank control group Celastrol $0.5 \mu \mathrm{mol} / \mathrm{L}$

Figure 2: (a) Apoptosis morphological changes of DU145 cells induced by Celastrol with Hoechst 33258 (24 h). (b) Effects of Celastrol on cell apoptosis with Annexin-V FITC/PI assay. Cells were treated with various concentrations of Celastrol for $24 \mathrm{~h}$. 


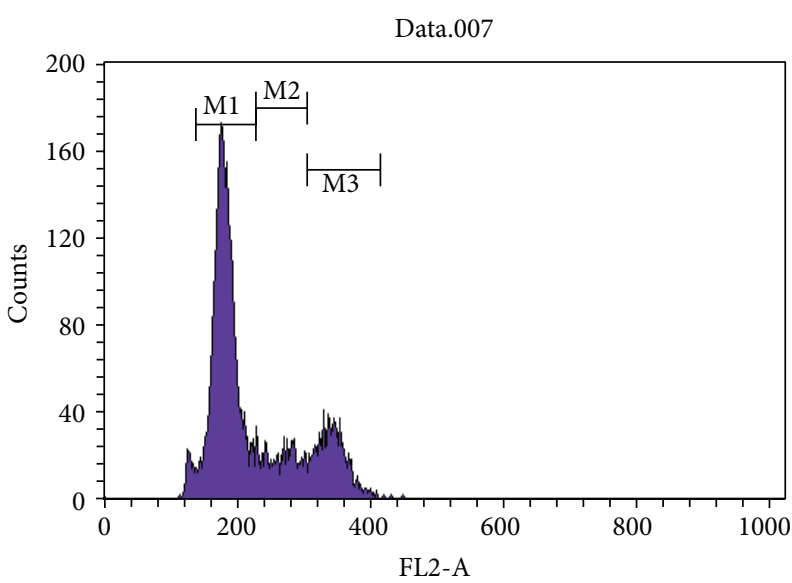

(a) Blank control group Celastrol $0.5 \mu \mathrm{mol} / \mathrm{L}$

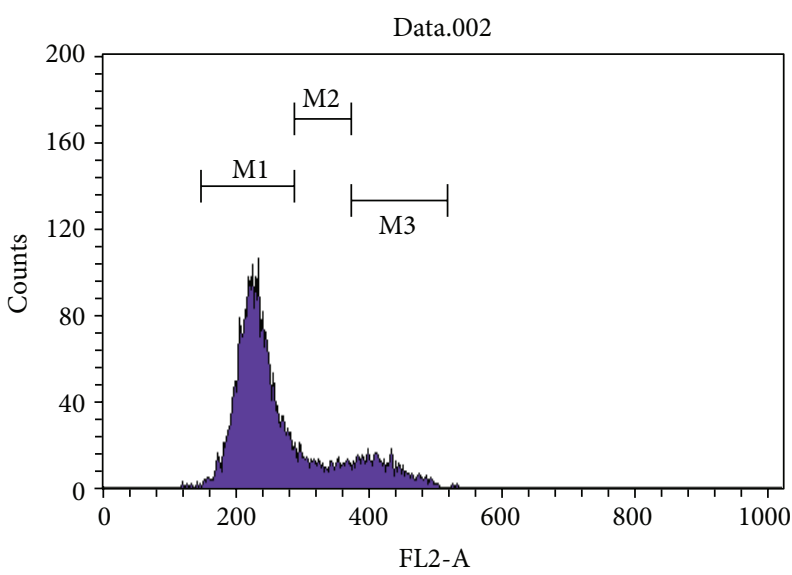

(c) Celastrol $1.0 \mu \mathrm{mol} / \mathrm{L}$

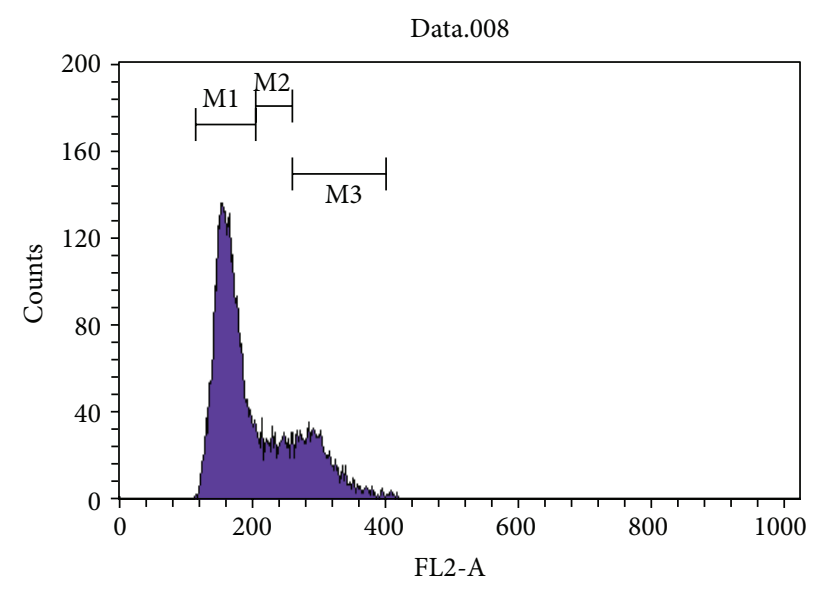

(b) Blank control group Celastrol $0.5 \mu \mathrm{mol} / \mathrm{L}$

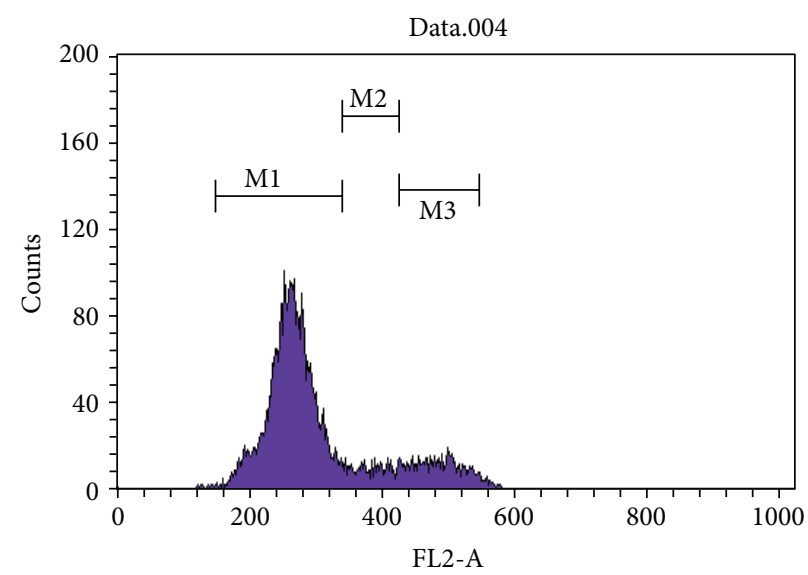

(d) Celastrol $2.0 \mu \mathrm{mol} / \mathrm{L}$

FIGURE 3: Effects of Celastrol on cell cycle distribution.

TABLE 1: Effects of Celastrol on cell cycle distribution and early apoptosis $(n=3, \pm S)$.

\begin{tabular}{|c|c|c|c|c|}
\hline \multirow{2}{*}{$\begin{array}{l}\text { Celastrol } \\
(\mu \mathrm{mol} / \mathrm{L}) \\
\end{array}$} & \multicolumn{3}{|c|}{ Cell cycle (\%) } & \multirow{2}{*}{$\begin{array}{c}\text { Apoptosis rate (\%) } \\
\text { Sub- } G_{1}\end{array}$} \\
\hline & $\mathrm{G}_{1} / \mathrm{G}_{0}$ & $\mathrm{~S}$ & $\mathrm{G}_{2} / \mathrm{M}$ & \\
\hline 0 (control) & $39.95 \pm 1.88$ & $49.45 \pm 1.67$ & $10.60 \pm 1.33$ & $2.88 \pm 0.33$ \\
\hline 0.5 & $40.48 \pm 2.34$ & $46.19 \pm 1.86$ & $13.33 \pm 1.84$ & $1.69 \pm 0.24$ \\
\hline 1.0 & $51.40 \pm 1.96^{* *}$ & $37.67 \pm 2.03^{* *}$ & $10.93 \pm 0.98$ & $3.25 \pm 0.78$ \\
\hline 2.0 & $68.58 \pm 2.89^{* *}$ & $23.29 \pm 1.52^{* *}$ & $8.13 \pm 1.02$ & $13.77 \pm 2.15^{* *}$ \\
\hline
\end{tabular}

${ }^{* *} P<0.01$ versus control group.

operating mainly by blocking DU145 cells at $\mathrm{G}_{0} / \mathrm{G}_{1}$ phase to have an apoptosis inducing effect has been reported in the literature [10].

Celastrol has become a hot spot of oncology field expression of ion channel proteins in normal and tumor cells. The ion channel proteins in numerous studies, tumor cell lines by hERG potassium channel protein encoded by the hERG gene as selective surface in different tissues and primary tumor cells, and tumor cell proliferation, differentiation, apoptosis, invasion, and sensitivity to chemotherapy are closely related and are considered to be the molecular target in cancer cells more specifically. In general, the hERG gene was only expressed in the early stages of embryonic development and followed by the inward rectifier potassium channel current it was replaced by [11]. HERG potassium channels are voltage gated ion channels typical in mammals. hERG due to the voltage dependence of fast inactivation exhibited strong inward rectification activities and played an important role in maintaining the differentiation and physiological function of normal heart rhythm and neurons $[12,13]$. In addition, hERG potassium channel is involved in a variety of ventricular arrhythmias and may be the cause of congenital long QT syndrome (LQTS) which is one of the major virulence factors [14]. As mentioned before, the hERG potassium 


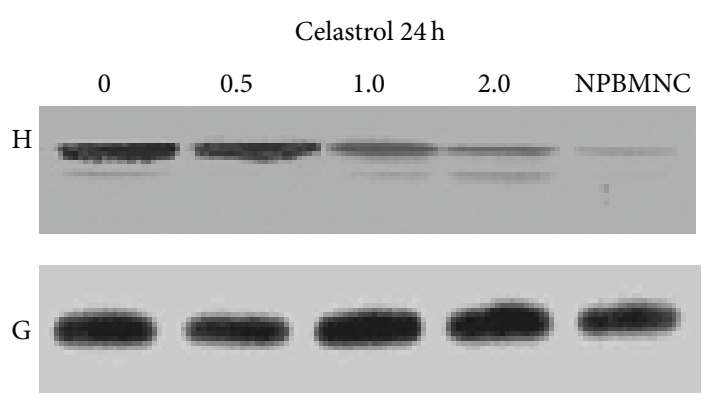

(a)

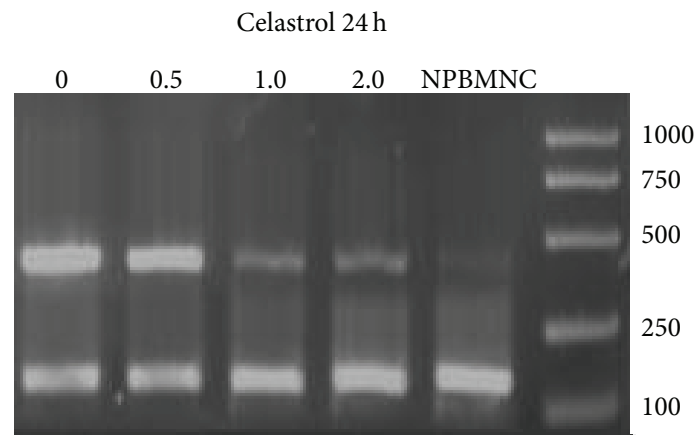

(b)

FIGURE 4: (a) Effects of Celastrol on the expression of hERG protein in DU145 cells and normal mononuclear cells with various concentrations for $24 \mathrm{~h}$. (b) Effects of Celastrol on the expression of hERG mRNA in DU145 cells and normal mononuclear cells with various concentrations for $24 \mathrm{~h}$.

channel protein is crucial in maintaining the cell resting membrane electric's localization in the polarization state, but new research shows that the proliferation characteristics and cell membrane limited tumor cell depolarization are closely related to the status, suggesting the protein and tumor cell proliferation activity of hERG potassium channel. And successive studies have confirmed that hERG protein was highly expressed in tumor cells and primary cells of various tissues of endometrial cancer, colon cancer, and neuroblastoma derived, while in the normal tissues or cells in the corresponding source, no expression or low expression of $[4,5]$ was found. In addition, a variety of tumor cells, which include the hERG potassium channel proteins, are also present in prostate cancer cells with high expression [3]. Blockade of the hERG potassium channel proteins by specific agents can inhibit the proliferation and metastasis of tumor cells and the corresponding $[15,16]$, increasing the sensitivity of tumor cells to chemotherapeutic drugs. At present, hERG potassium channel protein with tumor necrosis factor, integrin receptor, VEGF protein interaction, and active cancer protein [17-20] have been studied. It is not difficult to see that hERG potassium channel is a promising target for cancer therapy. Therefore, in this experiment, hERG gene as a target observe the red Chinese medicine Tripterygium wilfordii on DU145 cells of hERG potassium channel protein regulation. The results show that, compared with the mononuclear cells of normal control, the expression of hERG potassium channel protein levels rises to higher DU145 cell memory, while the normal mononuclear cells hardly show expression. For the effect of tripterine intervention, the protein and gene expression levels were concentrationdependent underground tune. The effect of tripterine on proliferation of DU145 cells and the intracellular expression of hERG potassium channel are closely related. Although confirmed in tumor cells, inhibition of hERG potassium channel protein expression can inhibit the proliferation of tumor cells, inducing tumor cell apoptosis. Tripterine is expected to become the hERG potassium channel protein inhibitor of a new generation.

Effects of hERG potassium channel protein on the biological behavior of the tumor that can inhibit the growth of tumor cells by inhibiting the expression or channel current of IhERG and promote tumor cell differentiation or apoptosis, reduce its invasiveness. There lays a good foundation for tumor targeting therapy and drug screening.

\section{Conflict of Interests}

The authors declare that there is no conflict of interests regarding the publication of this paper.

\section{Acknowledgment}

This work was supported by research grants from the Natural Science Foundation of Hubei Province of China (2011CDB236) to Youping Deng.

\section{References}

[1] W. Ping and W. Bo, "Study on the relationship between potassium channels and tumor progression of," International Journal of Pathology and Clinical Medicine, vol. 25, no. 6, pp. 488-491, 2005.

[2] W. Ping and W. Bo, "TASK-3 potassium ion channels of," International Journal of Pathology and Clinical Medicine, vol. 26, no. 3, pp. 225-231, 2006.

[3] S. Pillozzi, M. F. Brizzi, M. Balzi et al., "HERG potassium channels are constitutively expressed in primary human acute myeloid leukemias and regulate cell proliferation of normal and leukemic hemopoietic progenitors," Leukemia, vol. 16, no. 9, pp. 1791-1798, 2002.

[4] E. Afrasiabi, M. Hietamäki, T. Viitanen et al., "Expression and significance of HERG (KCNH2) potassium channels in the regulation of MDA-MB-435S melanoma cell proliferation and migration," Cellular Signalling, vol. 22, no. 1, pp. 57-64, 2010.

[5] I. Staudacher, L. Wang, X. Wan et al., "hERG K ${ }^{+}$channel-associated cardiac effects of the antidepressant drug desipramine," Naunyn-Schmiedeberg's Archives of Pharmacology, vol. 383, no. 2, pp. 119-139, 2011.

[6] H. Li, Y. Y. Zhang, X. Y. Huang et al., "Benificial effect of tripterine on systemic lupus erythmatosus induced by active chromatin in BALB/c mice," European Journal of Pharmacology, vol. 11, no. 2, pp. 231-237, 2005. 
[7] S. Abbas, A. Bhoumik, R. Dahl et al., "Preclinical studies of celastrol and acetyl isogambogic acid in melanoma," Clinical Cancer Research, vol. 13, no. 22, pp. 6769-6778, 2007.

[8] Y. Dai, J. T. DeSano, Y. Meng et al., "Celastrol potentiates radiotherapy by impairment of DNA damage processing in human prostate cancer," International Journal of Radiation Oncology Biology Physics, vol. 74, no. 4, pp. 1217-1225, 2009.

[9] I. Dogan, A. Cumaoglu, A. Aricioglu, and A. Ekmekci, "Inhibition of ErbB2 by Herceptin reduces viability and survival, induces apoptosis and oxidative stress in Calu-3 cell line," Molecular and Cellular Biochemistry, vol. 347, no. 1-2, pp. 41-51, 2011.

[10] A. Arcangeli, O. Crociani, E. Lastraioli, A. Masi, S. Pillozzi, and A. Becchetti, "Targeting ion channels in cancer: a novel frontier in antineoplastic therapy," Current Medicinal Chemistry, vol. 16, no. 1, pp. 66-93, 2009.

[11] C. Gessner, R. Macl-klene, J. C. Starkus et al., "The amiodarone derivative $\mathrm{KBl} 30015$ activates hERGl potassium channels via a navel mechanism," The European Journal of Pharmacology, vol. 632, no. 1-3, pp. 52-59, 2010.

[12] P. L. Smith, T. Baukrowitz, and G. Yellen, "The inward rectification mechanism of the HERG cardiac potassium channel," Nature, vol. 379, no. 6568, pp. 833-836, 1996.

[13] C. Jiang, D. Atkinson, J. A. Towbin et al., “Two long QT syndrome loci map to chromosomes 3 and 7 with evidence for further heterogeneity," Nature Genetics, vol. 8, no. 2, pp. 141-147, 1994.

[14] M. C. Sanguinetti and M. Tristani-Firouzi, "hERG potassium channels and cardiac arrhythmia," Nature, vol. 440, no. 7083, pp. 463-469, 2006.

[15] S. Z. Chen, S. H. Zhang, J. H. Gong, and Y. S. Zhen, "Erythromycin inhibits the proliferation of HERG $\mathrm{K}^{+}$channel highly expressing cancer cells and shows synergy with anticancer drugs," Zhonghua Yi Xue Za Zhi, vol. 86, no. 47, pp. 3353-3357, 2006.

[16] S. Z. Chen, M. Jiang, and Y. S. Zhen, "HERG K+ channel expression-related chemosensitivity in cancer cells and its modulation by erythromycin," Cancer Chemotherapy and Pharmacology, vol. 56, no. 2, pp. 212-220, 2005.

[17] H. Lin, J. Xiao, X. Luo et al., "Overexpression HERG K+ channel gene mediates cell-growth signals on activation of oncoproteins SP1 and NF- $\kappa$ B and inactivation of tumor suppressor Nkx3.1," Journal of Cellular Physiology, vol. 212, no. 1, pp. 137-147, 2007.

[18] A. Cherubini, G. Hofmann, S. Pillozzi et al., "Human ether-ago-go-related gene 1 channels are physically linked to $\beta 1$ integrins and modulate adhesion-dependent signaling," Molecular Biology of the Cell, vol. 16, no. 6, pp. 2972-2983, 2005.

[19] A. Masi, A. Becchetti, R. Restano-Cassulini et al., "hERG1 channels are overexpressed in glioblastoma multiforme and modulate VEGF secretion in glioblastoma cell lines," British Journal of Cancer, vol. 93, no. 7, pp. 781-792, 2005.

[20] S. Pillozzi, M. F. Brizzi, P. A. Bernabei et al., "VEGFR-1 (FLT1), $\beta 1$ integrin, and hERG $\mathrm{K}^{+}$channel for a macromolecular signaling complex in acute myeloid leukemia: role in cell migration and clinical outcome," Blood, vol. 110, no. 4, pp. 12381250, 2007. 

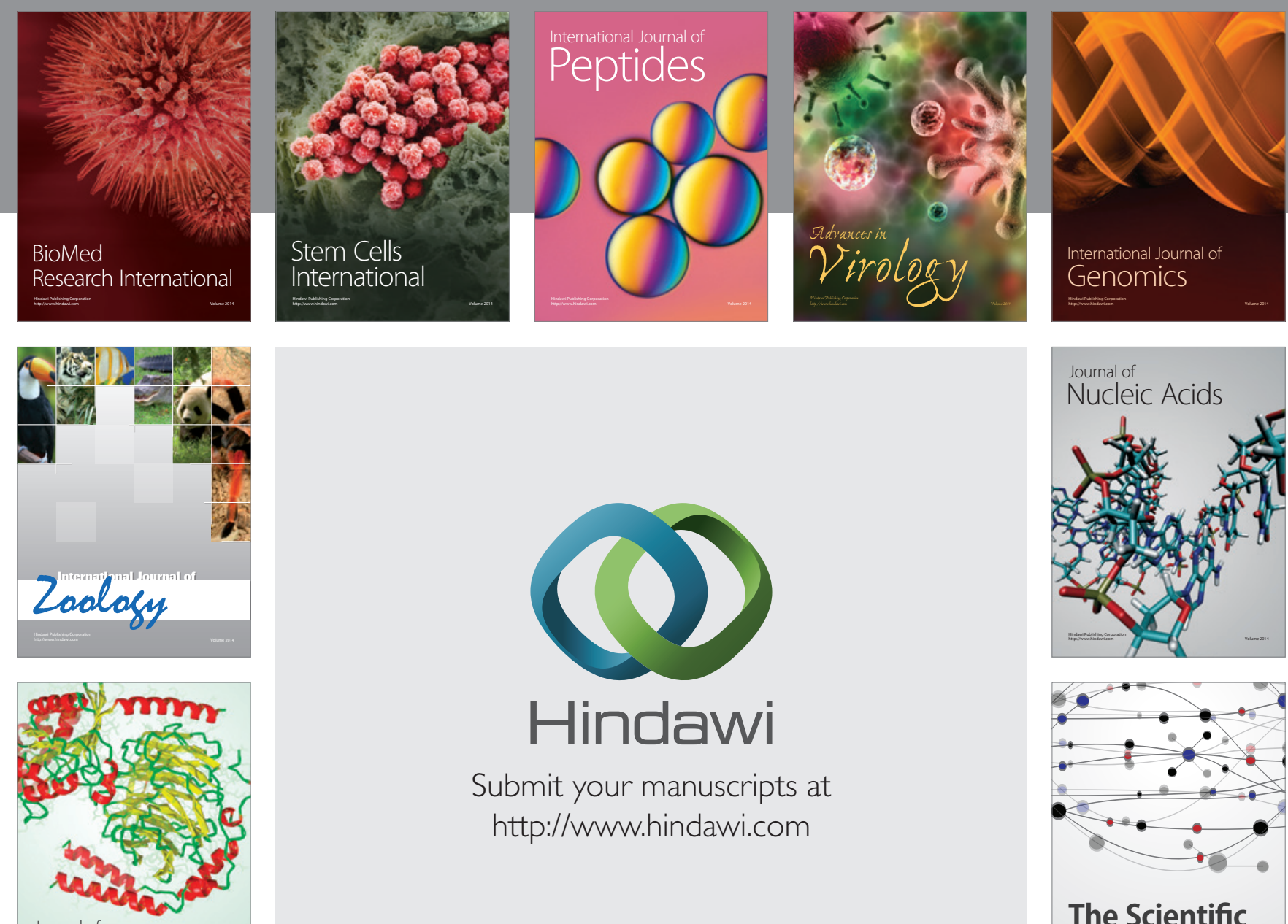

Submit your manuscripts at

http://www.hindawi.com

Journal of
Signal Transduction
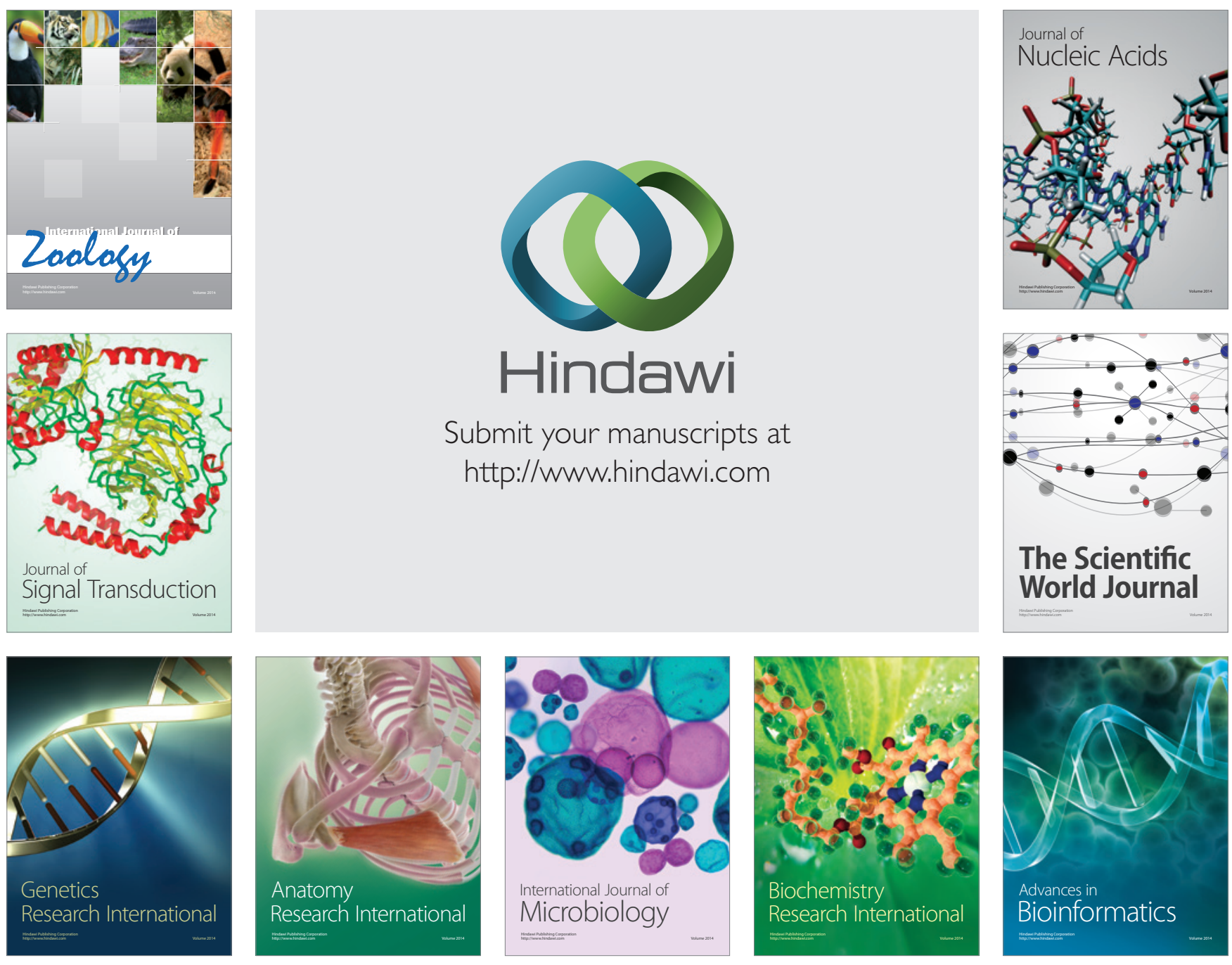

The Scientific World Journal
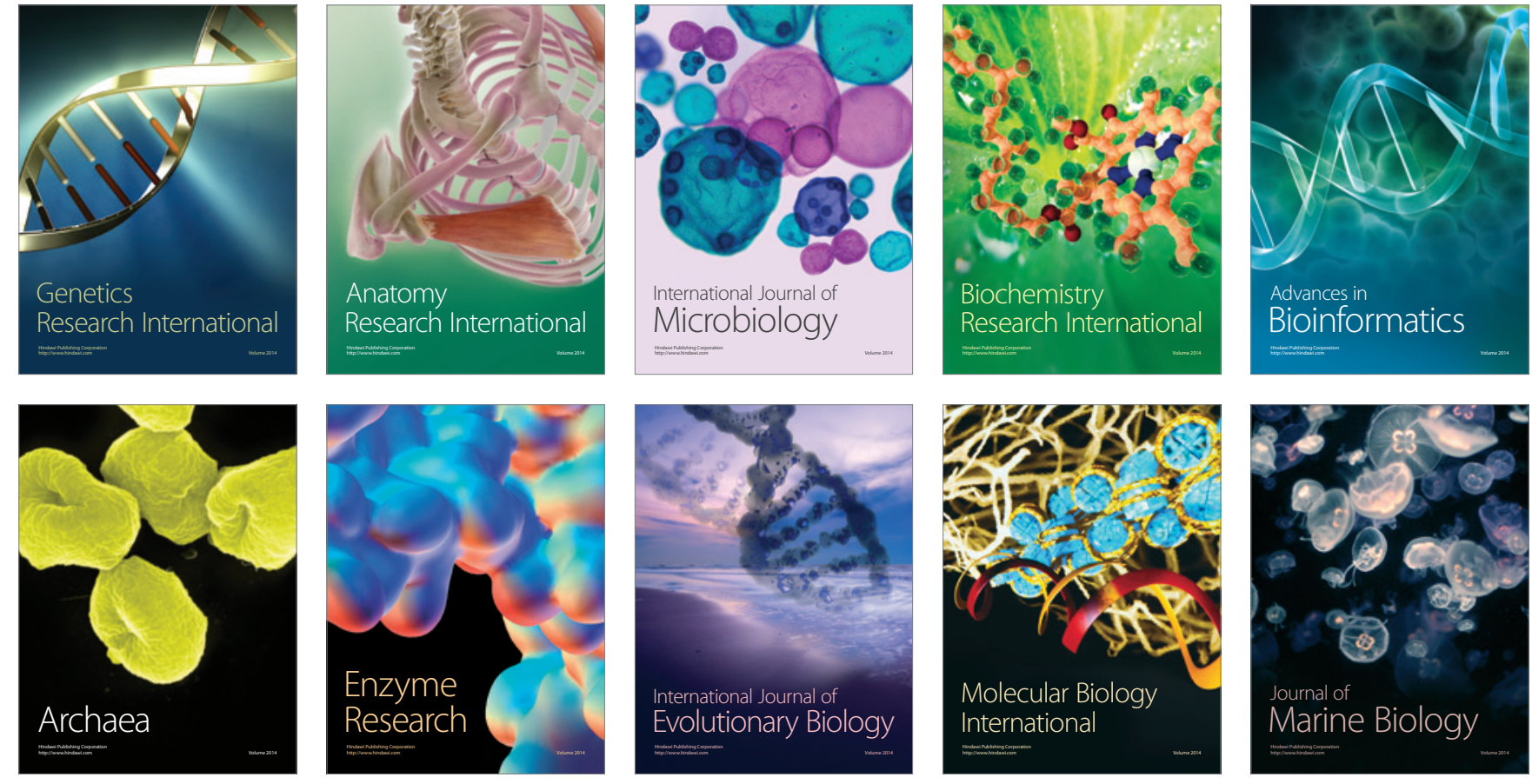